\author{
EWA RadomsKa \\ Uniwersytet Pedagogiczny im. Komisji Edukacji Narodowej w Krakowie \\ ORCID: https://orcid.org/0000-0002-9503-534X
}

\title{
Szanghaj jako międzynarodowe centrum finansowe - osiągnięcia i wyzwania dla dalszego rozwoju
}

\section{Shanghai as an international finance center - the achievements and challenges for further development}

\section{Abstract}

The purpose of the study was to analyze selected actions, which were and are important for Shanghai to obtain the status of the international financial center, together with an initial assessment of the achievements and an indication of the challenges for further development. The carried out analysis shows, that Shanghai strengthens its position as the world's leading international financial center. Whereas it is necessary for its further development to implement reliable market rules, that will give certainty to investors (domestic and foreign) that they have an open and fair access to the market and their interests are protected. The transparency and growing maturity of the stock market, the full liberalization of capital flows and the full interchangeability of the chinese currency play an important role. Whether Shanghai will be given the right to valuation global financial assets, depends to a significant extent on the alignment of China's economic development and progress in the internationalization of the yuan. It also depends on whether the leading foreign financial organizations will see Shanghai as the most important platform to draw dividends from China's economic development and the internationalization of the chinese currency. In the event of these basic conditions not being completed, Shanghai 
will not be able to become a fully global, mature financial center, integrated into the global financial system, taking into account, for example, the degree of internationalization of stock exchange operations.

Keywords: Shanghai, financial market, international finance center, yuan, China

\section{Шанхай как международный финансовый центр - достижения и вызовы для дальнейшего развития}

\section{Аннотация}

Целью исследования был анализ отдельных направлений деятельности, которые были и важны для Шанхая в получении статуса международного финансового центра, а также предварительная оценка его достижений и определение проблем для дальнейшего развития. Проведенный анализ показывает, что Шанхай укрепляет свои позиции в качестве ведущего международного финансового центра в мире. Для его дальнейшего развития необходимо внедрить надежные рыночные правила, которые дадут инвесторам (внутренним и иностранным) уверенность в том, что они имеют открытый и справедливый доступ на рынок и что их интересы защищены. Важную роль играют прозрачность и растущая зрелость фондового рынка, полная либерализация потоков капитала и полная конвертируемость китайской валюты. Получит ли Шанхай право на оценку глобальных финансовых активов, в значительной степени зависит от выравнивания экономического развития Китая и прогресса в интернационализации юаня. Также от того, будут ли ведущие иностранные финансовые организации рассматривать Шанхай как наиболее важную платформу для получения дивидендов от экономического развития Китая и интернационализации китайской валюты. Если эти основные условия не будут выполнены, Шанхай не сможет стать полностью глобальным зрелым финансовым центром, интегрированным с мировой финансовой системой, даже с учетом степени интернационализации биржевых операций.

Ключевые слова: Шанхай, финансовый рынок, международный финансовый центр, юань, Китай

\section{Wstęp}

7 mienia się globalna architektura finansowa XXI wieku. Wraz ze wzrostem siły gospodarczej Chin, Szanghaj jako najbardziej rozwinięte i zaludnione miasto Chin z 27,06 milionami mieszkańców (Macrotrends, 
2021) oraz trzecia największa aglomeracja świata (Thornton, 2019) wzmacnia swoją pozycję jako międzynarodowe centrum finansowe. Jest to zgodne z nakreśloną w 2009 roku wizją administracji centralnej kraju, która upatrywała w nim nie tylko głównego ośrodka finansowego w Azji, ale kluczowego centrum nowego układu ekonomicznego na świecie, które odpowiada potędze gospodarczej Chin oraz rosnącego znaczenia juana jako równoważnej dolarowi i euro waluty bazowej w handlu i przy zawieraniu transakcji inwestycyjnych. W ślad za planami, na przestrzeni lat podjęto szereg działań, aby podnieść status Szanghaju do rangi nowoczesnego centrum biznesowego i międzynarodowego centrum finansowego, których przyspieszenie obserwuje się od kilku lat. Nawet pandemia Covid-19 nie powstrzymała władz chińskich w urzeczywistnieniu planu, a napięcia handlowe między Stanami Zjednoczonymi i Chinami do zwiększenia aktywności inwestorów amerykańskich w Szanghaju.

Indeks globalnych centrów finansowych (Global Financial Centers Index, GFCI) publikowany co dwa lata przez Z/Yen Group, czołowy komercyjny think tank z siedzibą w Londynie oraz China Development Institute, think tank z Shenzhen w prowincji Guangdong ocenia konkurencyjność miast jako globalnych centrów finansowych. Bierze pod uwagę pięć obszarów: jakość otoczenia biznesowego, kapitał ludzki, infrastruktura, rozwój sektora finansowego i reputacja. Uwzględnia 134 czynniki instrumentalne oparte na danych wtórnych, w połączeniu z wynikami ponad trzech tysięcy kwestionariuszy wypełnionych przez specjalistów $\mathrm{z}$ branży usług finansowych na całym świecie. Szanghaj w ostatnich latach istotnie poprawił się we wskazanych obszarach, na tyle, aby w Global Financial Centers Index, opublikowanym w marcu 2021 roku, wyprzedzić Tokio jako trzecie centrum finansowe świata, po Nowym Jorku i Londynie, a przed Hongkongiem i Singapurem (Z/Yen Group, China Development Institute, 2021). W Chinach znajduje się 7 z 15 największych centrów finansowych na świecie mających potencjał do szybkiego wzrostu (Moody, 2020).

Przyglądając się historii ewolucji międzynarodowych centrów finansowych i rywalizacji o globalne przywództwo finansowe, można zauważyć, że centra te są ważnymi symbolami pozycji kraju w regionalnym, a nawet globalnym podziale pracy. Do pewnego stopnia centrum finansowe jest wynikiem mocnych stron kraju w produkcji i globalnym łańcuchu 
wartości. Uosabia ono narodowy (a nawet globalny) poziom technologiczny, wydajność, innowacyjność oraz zdolność do międzynarodowej koordynacji i przywództwa. Nowy Jork i Londyn, określane jako stolice kapitału (Cassis, 2006), swój sukces jako międzynarodowych centrów finansowych zawdzięczają w dużej mierze pozycji, odpowiednio USA i Wielkiej Brytanii w globalnej polityce, gospodarce i bezpieczeństwie. Mimo, że Brexit osłabił pozycję Wielkiej Brytanii, międzynarodowy wpływ jej waluty i rola Londynu jako międzynarodowego centrum finansowego oznaczają, że nadal jest to liczące się centrum finansowe. Dla Stanów Zjednoczonych sektor finansowy ma ogromne znaczenie. Po globalnym kryzysie finansowym w 2008 roku, kraj ten podjął wiele działań zmierzających do konsolidacji realnej gospodarki, aby umocnić pozycję Nowego Jorku jako międzynarodowego centrum finansowego. Chińskie działania na rzecz wzmocnienia pozycji Szanghaju w światowych finansach przyjmowano z niepokojem. Obawiano się wzmożonej konkurencji i konieczności dzielenia się „lukratywną częścią globalnego tortu" alokacji bogactwa.

Niektórzy badacze wskazują, iż Szanghaj wraca do pozycji, jaką cieszył się ostatnio przed wojną oporu przeciwko japońskiej agresji (1931-1945), kiedy to był potęgą finansową Azji (Moody, 2020). W latach trzydziestych miasto to miało status międzynarodowego centrum finansowego na Dalekim Wschodzie. Jednak Chiny były wtedy bardzo biedne i słabe. Jako centrum finansowe, Szanghaj zaspokajał więc głównie potrzeby zagranicznych firm prowadzących interesy w Chinach oraz chińskich grup interesu. Miasto nie miało wówczas dużego znaczenia strategicznego. Obecnie sytuacja wygląda odmiennie. Chiny stały się ważnym uczestnikiem rynku globalnego. Ich produkcja, handel i inwestycje są głęboko zintegrowane w globalnych łańcuchach wartości. Szanghaj traktowany jest jako jeden z motorów wzrostu Chin i dalszej integracji kraju z gospodarką światową.

Mimo wątpliwości, czy rzeczywiście Szanghaj jest obecnie wystarczająco gotowy i dojrzały, aby uznać go za wiodące globalne centrum finansowe świata (jak wynika z Global Financial Centers Index 2021), interesujące jest przeanalizowanie działań, które miały i mają znaczenie dla osiągnięcia przez Szanghaj statusu międzynarodowego centrum finansowego wraz ze wstępną oceną osiągnięć i wskazaniem wyzwań dla dalszego rozwoju, co stanowiło główny cel badań zaprezentowanych w artykule. Celowi temu 
podporządkowano strukturę artykułu. W części pierwszej wyjaśniono istotę, specyfikę i czynniki rozwoju międzynarodowego centrum finansowego w ujęciu teoretycznym, ale również z odniesieniem do przykładów Nowego Jorku i Londynu jako centrów finansowych. Część druga identyfikuje główne działania na rzecz budowy statusu Szanghaju jako międzynarodowego centrum finansowego. W części trzeciej scharakteryzowano rynki finansowe Szanghaju, ich mocne i słabe strony. Część czwarta dotyczy znaczenia rozwoju Szanghaju jako międzynarodowego centrum finansowego $\mathrm{z}$ perspektywy Chin. $\mathrm{W}$ podsumowaniu sformułowano rekomendacje, które według autorki są istotne dla dalszego rozwoju i wzmacniania Szanghaju jako międzynarodowego centrum finansowego. Wykorzystano metodę badawczą opisową, porównawczą, analityczną. Problematyka poruszana w artykule jest wstępnym etapem do kontynuowania badań nad uwarunkowaniami rozwoju i przeobrażeniami gospodarki chińskiej wraz z ich znaczeniem międzynarodowym.

\section{Międzynarodowe centrum finansowe - istota, specyfika, czynniki rozwoju}

Międzynarodowe centrum finansowe można zdefiniować jako takie, które łączy działalność onshore (świadczenie usług finansowych rezydentom i nierezydentom) i offshore (świadczenie usług finansowych nierezydentom, głównie w walutach zewnętrznych). Główne centra (Nowy Jork, Londyn, Tokio, do których dołączył ostatnio Szanghaj) pełnią obie funkcje, w przeciwieństwie do drugorzędnych ośrodków, takich jak np. Singapur i Hongkong, które zasadniczo pełnią funkcję offshore. Główne centra oferują kompleksowe usługi finansowe obejmujące rynki pieniężne, kapitałowe, instrumentów pochodnych i wymiany walut, podczas gdy centra drugorzędne są generalnie bardziej skoncentrowane na wybranych segmentach offshore, takich jak zarządzanie aktywami, ubezpieczenia i fundusze emerytalne, powiernictwo i zarządzanie nieruchomościami (IMF, 2000). Centra finansowe mogą zapewniać gospodarstwom domowym i firmom dostęp do głębokich, płynnych i zaawansowanych rynków finansowych oraz pełnić rolę ważnych ośrodków informacji, zarówno dla firm finansowych, jak i świadczących zaawansowane usługi biznesowe, m.in. doradztwa prawnego, księgowego, 
marketingowego i zarządczego (Coe, Lai, Wójcik, 2014). Firmy te odgrywają wiodącą rolę w dużych transakcjach finansowych, takich jak np. pierwsze oferty publiczne (nowe emisje papierów wartościowych), czy fuzje i przejęcia (Ioannou, Wójcik, Pažitka, 2021). Usługi finansowe i biznesowe to jeden z najszybciej rozwijających się sektorów gospodarki od kilkudziesięciu lat. Odnotowują one najszybszy wzrost w gospodarkach wschodzących (Cassis, Wójcik, 2018).

Istnienie centrów finansowych można wytłumaczyć wzajemnym oddziaływaniem sił dośrodkowych i odśrodkowych (Amin, Thrift, 1992; Grote, 2008; Engelen, Grote, 2009; McCann, 2001; Verdier, 2002; Taylor, Beaevrstock, Cook, Pandit, Pain, 2003; Degl'Innocenti, Matousek, Sevic, Tzeremes, 2017). Siły dośrodkowe można podzielić na korzyści lokalizacyjne i aglomeracyjne (McCann, 2001). Korzyści lokalizacyjne pozwalają firmom zlokalizowanym blisko siebie dzielić duży i głęboki rynek pracy, infrastrukturę i informacje. To z kolei pobudza konkurencję, współpracę, wdrażanie innowacji. Korzyści aglomeracyjne dotyczą korzyści z lokalizacji w dużych miastach, w pobliżu dużych grup klientów korporacyjnych, agencji rządowych, wyspecjalizowanych dostawców spoza sektora usług finansowych i biznesowych (np. firmy IT), infrastruktury wielkomiejskiej (np. lotniska międzynarodowe) oraz udogodnień poprawiających jakość życia (np. teatry, muzea, galerie sztuki). Centra finansowe działają również jako centra informacyjne zmniejszając asymetrie informacyjne, jednocześnie umożliwiając firmom i osobom fizycznym łączenie informacji lokalnych z globalnymi oraz ich interpretację. Informacje lokalne mogą odnosić się do konkretnej firmy lokalnej lub zasobów lokalnych, z kolei globalne informacje do globalnych trendów politycznych, gospodarczych, technologicznych. Intensywność wymiany informacji poprzez konkurencję, współpracę i innowacje w centrach finansowych pomaga budować wiedzę i zaufanie, których nie można łatwo wytworzyć ani przenieść na odległość (Amin, Thrift, 1992). Korporacyjni, a zwłaszcza detaliczni klienci sektora usług finansowych i biznesowych znajdują się w wielu lokalizacjach rozproszonych w krajobrazie gospodarczym, stąd potrzeba bycia blisko nich jest główną siłą odśrodkową wyjaśniającą powstawanie i rozwój centrów finansowych (Clark, O’Connor, 1997). Inną znaczącą siłą odśrodkową są nieefektywności aglomeracji, z wysokimi kosztami pracy i biur oraz presją zatorów z infrastrukturą na czele (Taylor, 
Beaevrstock, Cook, Pandit, Pain, 2003). Zdecentralizowane struktury polityczne, obecne zwłaszcza w krajach federalnych mają tendencję do ochrony lokalnych i regionalnych firm świadczących usługi biznesowe i finansowe oraz ich interesów, działając w ten sposób jako kolejna siła odśrodkowa (Verdier, 2002). Technologia ma współcześnie fundamentalne znaczenie dla rozwoju centrów finansowych. Pozwala wiodącym centrom finansowym mieć większy zasięg przestrzenny, ułatwia pozyskiwanie, gromadzenie i przetwarzanie danych oraz informacji z większego obszaru. Umożliwia uwolnienie łańcuchów wartości w sektorze biznesowym i finansowym, dzięki czemu back-office, mid-office i różnego rodzaju działania front-office mogą być zlokalizowane w różnych miejscach (Haberly, MacDonald-Korth, Urban, Wójcik, 2019).

Centra finansowe tworzą sieci i hierarchie. Ich sieciowy charakter odzwierciedla podstawowe przepływy danych i informacji, specjalistów, kapitału (Taylor, Derudder, 2015). Przepływy te opisują wysoki stopień komplementarności między centrami finansowymi. Przykładowo, rozwój Szanghaju w latach 90. i kolejnych dekadach XXI w. przyczynił się do nawiązania stosunków z Hongkongiem, z odrębną specjalizacją sektorową i zasięgiem geograficznym każdego ośrodka. Szanghaj odgrywał początkowo bardziej znaczącą rolę w kontaktach z krajowymi przedsiębiorstwami z tradycyjnych branż, takich jak górnictwo i przedsiębiorstwa użyteczności publicznej. Z kolei Hongkong był głównym ośrodkiem dla dużych chińskich przedsiębiorstw o zasięgu międzynarodowym, zwłaszcza z branż intensywnie korzystających $\mathrm{z}$ informacji, takich jak finanse i telekomunikacja (Karreman, van der Knaap, 2009). Centra finansowe pozostają jednocześnie głęboko zhierarchizowane, $\mathrm{z}$ dominacją wspomnianych miast: Nowego Jorku i Londynu. Przed globalnym kryzysem finansowym w 2008 roku, ich dominacja uległa jeszcze silniejszej konsolidacji, pomimo zmian w rankingach ośrodków tzw. drugiego i trzeciego stopnia. Po kryzysie, Nowy Jork i Londyn utrzymały swoje pozycje na szczycie hierarchii, są również bardziej podatne na wywołanie kryzysu (Wójcik, 2013). W bankowości inwestycyjnej (kluczowym obszarze działalności finansowej), Nowy Jork i Londyn pozostają dwoma wiodącymi ośrodkami od ponad wieku, pomimo rozwoju centrów finansowych w Azji, w tym Szanghaju (pozycja miasta w tym obszarze umacnia się). Hierarchia centrów finansowych jest ściśle związana $z$ ich 
łącznością oraz rodzajami usług finansowych i pokrewnych, które oferują swoim klientom. Centra finansowe mogą do pewnego stopnia specjalizować się w różnych typach usług finansowych i biznesowych oraz w różnych częściach łańcucha wartości. Mniejsze centra finansowe zazwyczaj koncentrują się na podstawowych usługach finansowych dla klientów detalicznych oraz małych i średnich przedsiębiorstw oraz mają jedynie lokalny lub regionalny zasięg rynkowy. Największe centra finansowe są zdywersyfikowane, mają duże i głębokie zasoby siły roboczej oraz obsługują rynki globalne, realizują największe transakcje finansowe dla klientów korporacyjnych i rządów (Wójcik, Pažitka, Knight, O’Neill, 2019).

Międzynarodowe centra finansowe powinny mieć dobrze rozwiniętą bazę ekonomiczną, wysoką intensywność handlu i inwestycji, dobrze rozwinięte i płynne rynki finansowe, odpowiednie ramy regulacyjne - pakiet „minimalnych przepisów / maksymalnych zachęt" dla pośredników finansowych (m.in. banków, domów maklerskich, funduszy hedgingowych, funduszy private equity/ venture capital, firm ubezpieczeniowych i innych niebankowych instytucji finansowych), solidną infrastrukturę fizyczną (taką jak telekomunikacja, transport, nieruchomości) wspieraną przez szereg usług pomocniczych, np. księgowość, usługi prawne, a także dużą dostępność wykwalifikowanej siły roboczej (IMF, 2000; Yusuf, Weiping, 2001; Laurenceson, Tang, Wong, 2003). Centra takie powinny działać zgodnie $\mathrm{z}$ akceptowalnymi na całym świecie standardami, dbać o wiarygodność, zaufanie, reputację.

\section{Działania na rzecz budowy statusu Szanghaju jako międzynarodowego centrum finansowego}

Chińskie miasta zmieniły się w szybkim tempie od czasu rozpoczęcia reform gospodarczych przez Denga Xiaopinga. Wprowadzając nowe, zdecentralizowane formy zarządzania uzyskały większą autonomię w alokacji dochodów, w realizacji własnych wizji rozwoju, ale spójnych z wizją rozwoju Chin (Wu, Xu, Yeh, 2007; Tasan-Kok, 2010). Podmioty finansowe i rynkowe instrumenty finansowe zyskały bardziej znaczącą rolę $\mathrm{w}$ realizacji inwestycji miejskich (Rutland, 2010; Robin, Brill, 2018). Pomysł ustanowienia Szanghaju jako międzynarodowego centrum finansowego Chin pojawił się po raz pierwszy w latach 90 . XX wieku, kiedy rozpoczęto otwieranie 
i rozwój strefy finansowo-handlowej Lujiazui (Chen 2007; Chen 2020). Z perspektywy czasu, dotknięte globalnym kryzysem finansowym 2008 roku Stany Zjednoczone i Europa potrzebowały Chin, co uświadomiło chińskim decydentom, że to ważny moment na zwiększenie wysiłków w realizacji pomysłu. Po raz pierwszy, w lipcu 2008 roku publicznie poparł go Wen Jiabao, ówczesny premier Chin. Władze Szanghaju od wielu lat zabiegały o jednoznaczne poparcie pomysłu przez Komitet Centralny Partii ChRL (Yugui, 2020). 25 marca 2009 roku Rada Państwa ogłosiła, iż do 2020 roku planuje się utworzenie międzynarodowego centrum finansowego w Szanghaju. System finansowy miasta i jakość świadczonych usług finansowych miały odpowiadać zarówno oczekiwaniom chińskich oraz zagranicznych inwestorów indywidualnych i korporacyjnych, jak i wymogom określanym przez globalne relacje gospodarcze, $w$ jakich Chiny coraz szerzej uczestniczą. Miesiąc później, na posiedzeniu wykonawczym Rady Państwa opublikowano dokument „Opinie Rady Stanu w sprawie promowania szybkiego rozwoju przemysłu nowoczesnych usług i przemysłu zaawansowanej produkcji w Szanghaju oraz uczynienia $\mathrm{z}$ niego międzynarodowego centrum finansowego i spedycyjnego" - szczegółowy plan, określając cele do osiągnięcia i kroki do podjęcia w celu wdrożenia strategii podniesienia statusu Szanghaju do rangi międzynarodowego centrum finansowego (She, 2010). Uznano, iż potrzebne jest stworzenie „,nowej przestrzeni” dla usług finansowych. W 2013 roku utworzono „Szanghajską Pilotażową Strefę Wolnego Handlu”, a idea jej uruchomienia wynikała z priorytetów ekonomicznych zapisanych w planie rozwoju społeczno-gospodarczego kraju na lata 2011-2015. Należały do nich m.in. dalsza stopniowa liberalizacja rozwiązań w zakresie obsługi handlu ze światem, tworzenie korzystniejszych warunków dla zagranicznych inwestorów, jak i stopniowa internacjonalizacja juana. Istotne znaczenie miało przetestowanie pełnego pakietu działań dotyczących inwestycji, sektora finansowego, ochrony własności intelektualnej, formalności związanych z podejmowaniem działalności gospodarczej (PricewaterhouseCoopers, 2013).

Wzrost zaangażowania władz centralnych w promocję i wspieranie działań na rzecz umacniania pozycji Szanghaju jako międzynarodowego centrum finansowego dostrzegalne było od 2009 roku, a ich intensywność szczególnie od 2019 roku, również na szczeblu władz Szanghaju. W styczniu 2019 roku Ludowy Bank Chin i siedem innych departamentów rządowych 
wspólnie opublikowały „Plan działania na rzecz budowy międzynarodowego centrum finansowego w Szanghaju (2018-2020)" wyraźnie artykułując cel uczynienia Szanghaju wpływowym podmiotem na światowym rynku finansowym. W przeprowadzonym w 2019 roku badaniu przez Amerykańską Izbę Handlową w Szanghaju, miasto poczyniło znaczne postępy, ale Izba wyraziła swój sceptycyzm wobec realnych możliwości utworzenia centrum do 2020 roku wskazując na kluczowe bariery: niewystarczającą otwartość wobec zagranicznych instytucji finansowych, małą przejrzystość i spójność w egzekwowaniu przepisów, istniejącą kontrolę przepływu kapitału, brak wysoko wykwalifikowanych specjalistów (Driscoll, Rechtschaffen, 2019, s. 3). Aby miasto stało się centrum finansowym na równi z Nowym Jorkiem czy Londynem, Chiny powinny według Izby m.in. znieść kontrolę kapitału, uczynić swoją walutę w pełni wymienialną, zakończyć arbitralną interwencję na rynku akcji wspieraną przez rząd, znieść ograniczenia internetowe w strefie finansowej miasta (Gibbs, 2019).

Inwestycje zagraniczne w ChRL są dozwolone, jeśli jednak dana branża lub obszar działania znajdują się na listach negatywnych, występują ograniczenia lub zakaz lokowania w nich kapitału zagranicznego. Publikowanie takich list zwiększa przejrzystość i jasność ograniczeń rządowych dotyczących inwestycji zagranicznych, uwzględnia również mechanizm dalszego redukowania liczby restrykcji. W Chinach istnieją 2 różne zestawy specjalnych środków administracyjnych (list negatywnych) w zakresie dostępu do inwestycji zagranicznych, jedna dla pilotażowych stref wolnego handlu (Lista Negatywna FTZ), druga dla pozostałej części kraju (Krajowa Lista Negatywna).W procesie dalszego otwierania gospodarki i poprawy otoczenia biznesowego oraz w powiązaniu $\mathrm{z}$ nową ustawą o inwestycjach zagranicznych ChRL (weszła w życie 1 stycznia 2020 roku), ustalono wcześniejszy niż w poprzednich latach termin aktualizacji obu list negatywnych. Zgodnie z listami negatywnymi z 2019 roku, udział inwestorów zagranicznych w spółkach akcyjnych, spółkach zarządzających funduszami inwestycyjnymi, spółkach kontraktów terminowych (futures) i zakładach ubezpieczeń na życie nie mógł przekraczać 51\%. 11 października 2019 roku i 13 marca 2020 roku Chińska Komisja Nadzoru Bankowo-Ubezpieczeniowego ogłosiła, że od 1 kwietnia 2020 roku powyższe ograniczenie dotyczące limitu udziału inwestorów zagranicznych zostanie zniesione. Znalazło to odzwierciedlenie 
w opublikowanych 23 czerwca 2020 roku dwóch zaktualizowanych listach negatywnych: Krajowej Liście Negatywnej 2020 (The Special Administrative Measures..., 2020) oraz Liście Negatywnej FTZ 2020 (The Free Trade Zone Special Administrative Measures..., 2020). Listy negatywne z 2019 roku uchylono. Ograniczenie maksymalnego udziału inwestorów zagranicznych zostało usunięte. Oznacza to otwarcie chińskiego sektora finansowego dla kapitału zagranicznego (i zgodne ze zobowiązaniami Chin w ramach „pierwszej fazy" umowy handlowej między USA i Chinami, która weszła w życie 14 lutego 2020 roku). Zaktualizowane listy negatywne z 2020 roku to kolejny krok naprzód w chińskiej reformie ukierunkowanej na większe otwarcie.

Kierując się wytycznymi władz centralnych, władze miejskie Szanghaju skupiły się na poprawie otoczenia dla rozwoju rynków finansowych i innowacji finansowych, zwiększeniu efektywności w alokacji środków finansowych. Zaktywizowały w ostatnich latach działania na rzecz rozwoju technologii blockchain starając się włączać banki i kluczowe firmy, aby przyjęły tę technologię dla zwiększenia efektywności finansowania łańcucha dostaw oraz na poprawie pozycji miasta w globalnym sektorze technologii finansowych (Fintech) (China Banking News, 2019). W 2016 roku 8 z 27 firm z branży Fintech na całym świecie, wycenionych na ponad 1 mld USD funkcjonowało w Chinach (World Bank, People's Bank of China, 2018).

O pozycji konkretnego miasta na światowej mapie finansowej decyduje także infrastruktura techniczna, w tym system łączności i systemy przetwarzania danych. W tym zakresie Szanghaj dokonał w ostatnich latach dużego postępu, zarówno pod względem hardware/sprzętu i oprogramowania, jak i nadzoru nad bezpieczeństwem transakcji przeprowadzanych w sieci. Sfera on-line staje się dla branży finansowej równie ważna, jak obszar „off-line” rozwija się ona w przypadku chińskiego sektora finansowego równie szybko, jak transakcje handlowe on-line /e-commerce. Nadal jednak występują w Chinach ograniczenia w swobodnym dostępie do Internetu będącego pod ścisłą kontrolą państwa, wymagając m.in. od firm takich jak np. Tencent Holdings Ltd. czy właściciela TikTok, ByteDance Ltd., cenzurowania i usuwania treści krytycznych wobec rządu i jego polityki. 


\section{Rynki finansowe Szanghaju - mocne i słabe strony}

Rynki finansowe mają kluczowe znaczenie dla funkcjonowania i dalszego rozwoju Szanghaju jako międzynarodowego centrum finansowego. Obecnie szanghajski system rynków finansowych jest dojrzałą platformą handlu akcjami, obligacjami, walutami, funduszami wymiany walut, towarami, kontraktami terminowymi, instrumentami pochodnymi i złotem. Oferuje stosunkowo pełną gamę produktów finansowych. W Szanghaju obecne są liczne instytucje finansowe. Wśród nich: Shanghai Stock Exchange (SSE) (giełda papierów wartościowych założona w 1990 roku), Shanghai Gold Exchange (SGE) (nadzoruje i reguluje handel złotem, srebrem, platyną i innymi wartościowymi metalami), Shanghai International Energy Exchange (INE) (umożliwia handel ropą naftową, gazem ziemnym oraz innymi produktami przemysłu petrochemicznego), Interbank Clearing House (Izba Rozliczeniowa odpowiedzialna m.in. za regulację rachunków handlowych transakcji clearingowych), Shanghai Futures Exchange (SHFE) (umożliwia handel w zakresie kontraktów terminowych miedzi, aluminium, cynku, kauczuku naturalnego, oleju opałowego i złota), China Foreign Exchange Trade System \& National Interbank Funding Center (odpowiada za operacje na międzynarodowym rynku walutowym, pieniężnym, rynku obligacji, kursu walutowego, stóp procentowych i instrumentów pochodnych) (Shanghai Finance, 2021). Według danych Instytutu Finansów Międzynarodowych CEIBS Lujiazui, pod koniec 2019 r. obroty na rynkach finansowych Szanghaju wyniosły 1934 biliony juanów ( 288 bilionów dolarów), czyli prawie osiem razy więcej niż dziesięć lat temu. Liczba licencjonowanych operacji finansowych w mieście w tym okresie wzrosła z 986 do 1646 (Hellenic Shipping News, 2020). Szanghajskie kontrakty terminowe na złoto, ropę itp. poprawiły międzynarodowe możliwości wyceny aktywów w chińskiej walucie, a Szanghaj stał się głównym ośrodkiem rozliczania globalnych płatności w juanach.

Sektor finansowy Szanghaju jest coraz bardziej umiędzynarodowiony. Chińskie akcje A i chińskie obligacje zostały włączone do głównych światowych indeksów. Uruchomiono inicjatywę Shanghai-Hong Kong Stock Connect (Yugui, 2020), choć wyzwaniem jest zapewnienie faktycznych korzyści z dostępu do rynków akcji w ramach giełd w Szanghaju i Hongkongu. Jak wykazały badania Ye Bai i Darien Yan Pang Chow (2017), wdrożenie 
Connect przyczyniło się do zwiększenia płynności i wielkości rynku, ale ma asymetryczny wpływ na rynki akcji w kontynentalnej części kraju i Hongkongu. Napędzają je niezrównoważone zmiany na obu rynkach.

W aspekcie rynków finansowych Szanghaju, warto zwrócić uwagę na opinię Zhanga Yuguia, dziekana Wydziału Ekonomii i Finansów Uniwersytetu Studiów Międzynarodowych w Szanghaju. W lutym 2020 roku wyraził swój sceptycyzm wobec ambicji Szanghaju stania się światowej klasy centrum finansowym w krótkim czasie. Krajowa konkurencja ze strony Pekinu, gdzie kształtowana jest polityka finansowa i znajdują się siedziby głównych organizacji finansowych oraz Shenzhen, najbardziej innowacyjnego regionu Chin i testowego dla finansowania cyfrowego oznacza według niego, że w przeciwieństwie do Nowego Jorku i Londynu, Szanghaj nie cieszy się pełnym poparciem świata, a nawet Chin w zakresie alokacji środków finansowych. Chociaż Szanghaj jest najbardziej rozwiniętym rynkiem finansowym w Chinach, znajduje się ponad $1000 \mathrm{~km}$ od Pekinu. Nawet przy nowoczesnych środkach transportu i komunikacji, problem braku synchronizacji decyzji z rynkiem nie może być skutecznie rozwiązany. Naukowcy w komisji polityki pieniężnej (doradza bankowi centralnemu w zakresie jego polityki pieniężnej) pochodzą głównie $\mathrm{z}$ renomowanych uniwersytetów i instytucji badawczych, takich jak Uniwersytet Pekiński, Uniwersytet Tsinghua, Uniwersytet Renmin w Chinach, Chińska Akademia Nauk Społecznych i Centrum Badań nad Rozwojem Rady Państwa. Trudno byłoby w niej znaleźć eksperta z uniwersytetu czy instytucji badawczej z Szanghaju (Yugui, 2020).

Pod względem jakości rynków finansowych, przyjazności dla biznesu, międzynarodowego charakteru i standardów obsługi rynków czynników produkcji oraz obecności na rynku kapitału zagranicznego, Szanghaj jest nadal daleko w tyle za Nowym Jorkiem i Londynem, a zniwelowanie tej różnicy wymaga czasu. Podczas, gdy Giełda Papierów Wartościowych w Szanghaju (SSE) wdrożyła takie inicjatywy, jak Shanghai-Hong Kong Stock Connect i Shanghai-London Stock Connect, a jej giełda znajduje się w pierwszej piątce na świecie pod względem wielkości, zagraniczne firmy odpowiadają za mniej niż 0,5 proc. wyemitowanych akcji znajdujących się w obrocie na giełdzie. Dla porównania, udział firm zagranicznych wynosi odpowiednio 32 proc. i 16 proc. na giełdzie nowojorskiej (NYSE) i londyńskiej (LSE). Inwestorzy zagraniczni stanowią ponad 20 proc. wszystkich inwestorów na 
NYSE, a na giełdzie w Szanghaju jest ich mniej niż 2 proc. W przypadku chińskiego rynku obligacji, mimo, że udział inwestycji zagranicznych na tym rynku wzrósł do 2 proc., jest to słaby wynik w porównaniu z sytuacją w USA. W samych amerykańskich papierach skarbowych organizacje zagraniczne odpowiadają za 20 proc. inwestycji. W odniesieniu do rynku kontraktów terminowych i instrumentów pochodnych, Szanghaj jest również daleko w tyle za Nowym Jorkiem. Jeśli chodzi o rozwój globalnego centrum alokacji aktywów i cen w chińskiej walucie, od 2015 roku dokonano znacznego postępu. Yugui uważa, iż umiędzynarodowienie juana jest samo w sobie monumentalnym przedsięwzięciem. Byłoby dość niezwykłe, gdyby Szanghaj mógł osiągnąć swój cel, jakim jest stanie się globalnym centrum wyceny aktywów w walucie chińskiej do 2030 roku.

W Szanghaju ulokowanych jest wiele firm finansowych z branży bankowej, rynku ubezpieczeń i usług finansowych. Swoje siedziby ma w mieście wiele zagranicznych banków, w tym m.in. Bank of New York, Mees Pierson Bank, Overseas Union Bank, ANZ Bank, Korean Development Bank, HSBC, Swedbank czy Deutsche Bank. Otwarcie chińskiego sektora finansowego w 2020 roku poprzez zniesienie ograniczeń maksymalnego udziału inwestorów zagranicznych ma znaczenie dla europejskich, amerykańskich i pochodzących $\mathrm{z}$ innych krajów instytucji finansowych. W ostatnich latach, limity kapitałowe zostały również zniesione w bankowości. Jednak późne otwarcie sektora, który był już zdominowany przez chińskie banki państwowe, zdaniem Izby Handlowej UE pozostawiło bankom z innych krajów jedynie niszowe możliwości. Co więcej, obszary, które ich najbardziej interesowały, zwłaszcza usługi transgraniczne wymagały licencji. Pozostawały one poza zasięgiem większości (The European Union Chamber of Commerce, 2020).

Pomimo tego sceptycyzmu, trwających napięć handlowych między Stanami Zjednoczonymi a Chinami, w warunkach otwarcia chińskiego sektora finansowego na zagraniczną konkurencję, pandemii Covid-19 „pod kontrolą” oraz relatywnie dobrych wskaźników makroekonomicznych (w stosunku do Europy, czy USA), w tym prognozowanego przez Haver Analytics, MFW, Morgan Stanley Research realnego wzrostu PKB Chin: 5,9 proc. w 2021 roku (Morgan Stanley, 2019), a także dużego, chłonnego rynku, czołowe amerykańskie instytucje finansowe z Wall Street zdecydowały się w 2020 roku na zwiększenie swojej aktywności w Szanghaju. JP Morgan, 
amerykański bank inwestycyjny i jego główny konkurent, Morgan Stanley otrzymali w marcu 2020 roku ostateczne zezwolenia regulacyjne na przejęcie większości udziałów w ich chińskich spółkach joint venture (Yan, Zhu, 2020). Blackrock, globalna firma zarządzająca funduszami inwestycyjnymi z siedzibą w Nowym Jorku, w sierpniu 2020 roku otrzymała pozwolenie na prowadzenie działalności w Chinach (Bloomberg, 2020). Wzrost obecności zagranicznych instytucji finansowych zintensyfikuje konkurencję na rynkach finansowych Szanghaju. Zhang Yugui (2020) ocenia, iż Szanghaj ugruntuje swoją pozycję jako międzynarodowe centrum finansowe, gdy firmy technologiczne z USA, Europy i Japonii będą starać się o wejście na giełdę SSE Science and Technology Innovation (tak jak Alibaba wszedł na giełdę Nasdaq).

\section{Znaczenie rozwoju Szanghaju jako międzynarodowego centrum finansowego z perspektywy Chin}

Promując Szanghaj jako międzynarodowe centrum finansowe, przy okazji spotkań najwyższego szczebla (np. podczas szczytów krajów BRICS), prezydent Chin Xi Jinping podkreśla rolę utworzenie międzynarodowego Azjatyckiego Banku Rozwoju (NDB) zajmującego się finansowaniem wspólnych projektów w zakresie rozbudowy infrastruktury m.in. transportowej i w sektorze energetycznym oraz zapewnienie działań stabilizujących w celu przeciwdziałania ewentualnym przyszłym kryzysom na globalnym rynku finansowym. Bank, z siedzibą w Szanghaju, traktowany jest przez władze chińskie jako przeciwwaga dla zachodnich instytucji finansowych, takich jak Bank Światowy, czy Międzynarodowy Fundusz Walutowy. Prezydent promuje również Inicjatywę Pasa i Szlaku (BRI), Azjatycki Bank Inwestycji Infrastrukturalnych (AIIB), Fundusz Jedwabnego Szlaku (Silk Road Fund) jako koła napędowe dla pogłębiania współpracy gospodarczej oraz wprowadzania nowych rozwiązań w systemie finansowym i monetarnym. Władze centralne Chin oczekują, że międzynarodową pozycję Szanghaju ugruntuje szersza „obsługa finansowa” projektów związanych z realizacją Inicjatywy Pasa i Szlaku (BRI) (Johnson, 2016; Cai, 2017), czy inicjatywy The Greater Bay Area (GBA), ambitnego projektu - spójnego ze strategią Made in China 2025) (Shang-Jin, Xie, Zhang, 2017) - połączenia dziewięciu miast w Delcie 
Rzeki Perłowej w prowincji Guangdong na południowym wybrzeżu Chin oraz dwóch SRA: Hongkongu i Makao w celu zbudowania globalnego klastra miejskiego stanowiącego zintegrowane centrum gospodarcze i biznesowe (Outline Development Plan..., 2019). Oczekuje się, że instytucje finansowe w Szanghaju zwiększą swoje doświadczenie w zakresie finansowania złożonych przedsięwzięć inwestycyjnych, głównie w infrastrukturze (transport, energetyka, ochrona środowiska) itp. Budowanie układów międzynarodowych w oparciu o siedzibę w Szanghaju, już nie tylko przez samych Chińczyków, ale także za zgodą pozostałych partnerów Chin, głównie w Azji umacnia rolę tego miasta jako światowej stolicy finansowej.

Z punktu widzenia władz Chin, rozwój Szanghaju jako międzynarodowego centrum finansowego ma również znaczenie dla poprawy międzynarodowej konkurencyjności tych chińskich firm, którym generalnie brakuje skali i wystarczającej zdolności konkurencyjnej, a są one niezbędne dla efektywnego działania na rynkach międzynarodowych (Bhattacharya, 2011). Szanghaj stopniowo odgrywa coraz większą rolę w stymulowaniu pierwszych ofert publicznych (IPO) akcji chińskich firm prywatnych (Szanghaj jest już największym rynkiem na świecie dla IPO dużych, kontrolowanych przez państwo chińskich firm) oraz przyciąganiu funduszy private equity/ venture capital w celu rozwoju rynku onshore denominowanego w juanach. Skorzystałyby z niego chińskie przedsiębiorstwa, które do niedawna musiały szukać finansowania w centrach offshore, takich jak Hongkong. Rząd podjął kilka prób poprawy dostępu chińskich przedsiębiorstw prywatnych do finansowania bankowego i na rynku kapitałowym. Uprościł przepisy i regulacje administracyjne, aby delegować uprawnienia decyzyjne do lokalnych oddziałów banków, a także aby zachęcić prywatne lokalne firmy do pozyskiwania walut obcych w kraju na inwestycje zagraniczne (Cong, 2009). Dostęp chińskich firm prywatnych nawet do finansowania w walucie lokalnej, nie mówiąc już o finansowaniu w walucie obcej, wciąż jest jednak niewystarczający. Preferencyjnie traktowane są duże konglomeraty państwowe. 


\section{Podsumowanie}

Proces rozwoju Szanghaju jako międzynarodowego centrum finansowego rozłożony był na lata i wciąż trwa. Na rozwój miasta od czasu rozpoczęcia reform gospodarczych istotny wpływ miało wprowadzenie nowych, zdecentralizowanych formy zarządzania, dzięki czemu Szanghaj uzyskał większą autonomię w alokacji dochodów zgodnie $\mathrm{z}$ własną wizją, ale spójną z wizją rozwoju Chin. W warunkach niedoboru finansów i konieczności pozyskiwania ich z różnych źródeł oraz rosnącego wpływu rynków finansowych na rozwój gospodarki i społeczeństwa (tzw. finansjalizacja), podmioty finansowe i rynkowe instrumenty finansowe zyskały bardziej znaczącą rolę w realizacji inwestycji, istotnych do zbudowania nowoczesnej bazy ekonomicznej miasta. Ostatnie lata to duża aktywność władz centralnych w rozwój i promocję Szanghaju jako międzynarodowego centrum finansowego, istotnego również dla wzmacniania roli Chin na globalnych rynkach finansowych. Wprowadzono korzystne rozwiązania prawne dla rozwoju rynków finansowych i usług finansowych, dla intensyfikacji konkurencji poprzez otwarcie branży finansowej dla inwestorów zagranicznych, których aktywność rośnie. Dalszemu rozwojowi Szanghaju jako międzynarodowego centrum finansowego sprzyjać będzie rosnący popyt na profesjonalne usługi finansowe (giełda, sektor ubezpieczeniowy itp.), który zgłasza w kraju zwiększająca się chińska klasa średnia, w tym zamożni inwestorzy prywatni. W stosunku do innych zaawansowanych gospodarczo państw, system emerytalny, czy ubezpieczenia społeczne są w Chinach wciąż na wczesnym etapie rozwoju, co w powiązaniu $\mathrm{z}$ procesem starzenia się społeczeństwa chińskiego daje obiecujące perspektywy rozwojowe dla funduszy emerytalnych, firm ubezpieczeniowych.

Dla dalszego rozwoju Szanghaju jako międzynarodowego centrum finansowego niezbędna jest implementacja wiarygodnych reguł rynkowych, które dadzą pewność inwestorom, zarówno krajowym, jak i zagranicznym, że mają otwarty i sprawiedliwy dostęp do rynku, a ich interesy są chronione. Filarami silniejszej pozycji Szanghaju jako centrum finansowego i podstawą wiarygodności jego rynków finansowych będą w dużej mierze dwa elementy: transparentność i rosnąca dojrzałość rynku giełdowego, jak i rzeczywista liberalizacja przepływów kapitałowych oraz realizacja celu, jakim jest pełna wymienialność chińskiej waluty. Konieczne są dalsze działania na rzecz 
umiędzynarodowienia juana. Rząd pilotuje programy umiędzynarodowienia chińskiej waluty poprzez swapy walutowe z innymi krajowymi bankami centralnymi i rozlicza transakcje handlowe w juanach (zamiast dolarów lub euro), ale to dopiero początek. To, czy Szanghaj uzyska prawa do wyceny globalnych aktywów finansowych w juanach, zależy w istotnym stopniu od wyrównania rozwoju gospodarczego Chin i postępów w umiędzynarodowieniu chińskiej waluty. Również od tego, czy czołowe zagraniczne organizacje finansowe będą postrzegały Szanghaj jako najważniejszą platformę do czerpania dywidend $\mathrm{z}$ rozwoju gospodarczego Chin i umiędzynarodowienia chińskiej waluty. W przypadku braku spełnienia tych podstawowych warunków, Szanghaj nie będzie mógł stać się w pełni globalnym, dojrzałym centrum finansowym, zintegrowanym ze światowym systemem finansowym biorąc choćby pod uwagę stopień internacjonalizacji operacji giełdowych.

\section{DR EWA RADOMSKA}

\section{Katedra Ekonomii i Polityki Gospodarczej \\ Instytut Prawa i Ekonomii \\ Wydział Nauk Społecznych \\ Uniwersytet Pedagogiczny im. Komisji Edukacji Narodowej w Krakowie \\ ul. Podchorążych 2, 30-084 Kraków \\ ewa.radomska@up.krakow.pl}

\section{Bibliografia}

Amin, A., Thrift, N. (1992). Neo-Marshallian nodes in global networks. International Journal of Urban and Regional Research, 16, 571-587.

Bai, Y., Chow, D.Y.P. (2017). Shanghai-Hong Kong Stock Connect: An analysis of Chinese partial stock market liberalization impact on the local and foreign markets. Journal of International Financial Markets, Institutions and Money, 50, 182-203.

Bhattacharya, A.K. (2011). The Feasibility of Establishing an International Financial Center in Shanghai. Journal of Asia-Pacific Business, 12(2), 123-140.

Bloomberg (2020, 29 August). BlackRock Gets Approval to Set Up Mutual Fund Company in China. Pobrane z: https://www.bloomberg.com/news/articles/2020-08-29/ blackrock-gets-approval-to-set-up-mutual-fund-company-in-china.

Cai, P. (2017, March). Understanding China's Belt and Road Initiative. Analysis. Sydney: Lowy Institute for International Policy. 
Cassis, Y. (2006). Capitals of Capital: A History of International Financial Centres, 17802005. Cambridge: Cambridge University Press.

Cassis, Y., Wójcik, D. (2018). International Financial Centres after the Global Financial Crisis and Brexit. Oxford: Oxford University Press.

Chen, Y. (2007). Shanghai Pudong: Urban Development in an Era of Global-local Interaction. Amsterdam: IOS Press.

Chen, Y. (2020). Financialising urban redevelopment: Transforming Shanghai's waterfront. Land Use Policy, 105-126.

China Banking News (2019, 31 October). PBOC Launches Measures to Boost Shanghai's Fintech Sector. Pobrane z: https://www.chinabankingnews.com/2019/10/31/ pboc-launches-measures-to-boost-shanghais-fintech-sector.

China Banking News (2019, 13 December). Shanghai Seeks to Establish Fintech $\mathrm{Hub}$ and Regulatory Sandbox in Pudong District. Pobrane z: https://www. chinabankingnews.com/2019/12/13/shanghai-establishing-fintech-hub-and -regulatory-sandbox-in-pudong-district.

Clark, G.L., O'Connor, K. (1997). The informational content of financial products and the spatial structure of the global finance industry. W: K.R. Cox (ed.), Spaces of Globalization: Reasserting the Power of the Local (89-114). New York: The Guilford Press.

Coe, N., Lai, K., Wójcik D. (2014). Integrating Finance into Global Production Networks. Regional Studies, 48(5), 761-777.

Cong, J. (2009). Chinese informal financial systems and economic growth - A case study of China's small and medium enterprises. Public Policy Review, 5(1), 63-88.

Degl'Innocenti, M., Matousek, R., Sevic, Z., Tzeremes, N.G. (2017). Bank Efficiency and Financial Centres: Does Geographical Location Matter? Journal of International Financial Markets, Institutions and Money, 46, 188-198.

Driscoll, I., Rechtschaffen, D. (2019, March). Shanghai 2020: A Financial Vision Unfulfilled. The American Chamber of Commerce Viewpoint.

Engelen, E., Grote, M.H. (2009). Stock exchange virtualisation and the decline of second-tier financial centres - the cases of Amsterdam and Frankfurt. Journal of Economic Geography, 9(5), 679-696.

Gibbs, K. (2019, 25 April). Shanghai can be made a global financial hub - if China fixes some fixable problems. South China Morning Post. Pobrane z: https:// www.scmp.com/comment/insight-opinion/article/3007412/shanghai-can -be-made-global-financial-hub-if-china-fixes.

Góralczyk, B. (2018). Wielki renesans. Chińska transformacje i jej konsekwencje. Warszawa: Wydawnictwo Akademickie Dialog.

Grote, M.H. (2008). Foreign banks' attraction to the financial Centre Frankfurt - An inverted 'U'-shaped relationship. Journal of Economic Geography, 8(2), 239-258.

Haberly, D., MacDonald-Korth, D., Urban, M., Wójcik, D. (2019). Asset management as a digital platform industry: a global financial network perspective. Geoforum, 106, 167-181.

HellenicShippingNews(2020,2 November).Shanghairisesonglobalfinancialstage. Pobrane z: https://www.hellenicshippingnews.com/shanghai-rises-on-global-financial-stage.

IMF (2000, 23 june). Offshore financial centers, IMF Background Paper. Washington: Monetary and Exchange Affairs Department. 
Ioannou, S., Wójcik, D., Pažitka, V. (2021). Financial centre bias in sub-sovereign credit ratings. Journal of International Financial Markets, Institutions and Money, 70 (C).

Johnson, Ch.K. (2016). President Xi Jinping's 'Belt and Road' Initiative: A Practical Assessment of the Chinese Communist Party's Roadmap for China's Global Resurgence. Center for Strategic and International Studies - CSIS Report.

Karreman, B., van der Knaap, B. (2009). The financial centres of Shanghai and Hong Kong: Competition or complementarity? Environment and Planning A: Economy and Space, 41(3), 563-580.

Laurenceson, J., Tang, K.K., Wong, H.M. (2003, 2-3 October). Shanghai as an international financial centre. Proceedings of the 15th Annual Conference of the Association for Chinese Economics Studies Australia (1-29). Brisbane: University of Queensland.

Macrotrends (2021). Shanghai, China Metro Area Population 1950-2021. Pobrane z: https://www.macrotrends.net/cities/20656/shanghai/population.

McCann, P. (2001). Urban and Regional Economics. Oxford: Oxford University Press.

Marszałek-Kawa, J. (red.). (2010). Chiny supermocarstwem XXI wieku? Rozważania na temat polityki i gospodarki Państwa Środka. Toruń: Wydawnictwo Adam Marszałek.

Marszałek-Kawa, J., Dmochowski, T. (red.). (2018). Rozważania o kierunkach współczesnej polityki Chin. Toruń: Wydawnictwo Adam Marszałek.

Moody, A. (2020, 3 November). Shanghai's role as global financial hub sure to expand. China Daily. Pobrane z: https://www.chinadaily.com.cn/a/202011/03/WS5fa0c6eaa31024ad0ba82c46.html.

Morgan Stanley (2019, 13 December). 2020 Global Macro Outlook: Calmer Waters Ahead. Pobrane z: https://www.morganstanley.com/ideas/global-economic-outlook-2020.

Outline Development Plan for the Guangdong-Hong Kong-Macao Greater Bay Area (2019). Pobrane z: https://www.bayarea.gov.hk/filemanager/en/share/pdf/Outline_Development_Plan.pdf.

PricewaterhouseCoopers (2013). China (Shanghai) Pilot Free Trade Zone. Pobrane z: http://www.iberchina.org/files/shanghai_free_trade_zone_pwc.pdf.

Robin, E., Brill, F. (2018). The global politics of an urban age: creating 'cities for all' in the age of financialisation. Palgrave Communications, 4(3), 1-5.

Rutland, T. (2010). The Financialization of Urban Redevelopment. Geography Compass, 4 (8), 1167-1178.

Shang-Jin, W., Xie, X., Zhang, X. (2017). From „Made in China” to „Innovated in China”: Necessity, Prospects, and Challenges. Journal of Economic Perspectives, 31(1), 49-70.

Shanghai Finance (2021). Construction of Shanghai Financial Market System. Pobrane z: http://en.jrj.sh.gov.cn/financial-centre/financial-market/134.shtml.

She, M. (2010, 24 March). The decision clearly shows the central government's determination to fight the global financial crisis. China Daily.

Tasan-Kok, T. (2010). Entrepreneurial governance: challenges of large-scale property-led urban regeneration projects. Journal of Economic and Human Geography, 101(2), 126-149.

Taylor, P., Derudder, B. (2015). World City Network: A Global Urban Analysis. New York: Routledge.

Taylor, P., Beaevrstock, J., Cook, G., Pandit, N., Pain, K. (2003). Financial clustering and its significance for London. London: City of London Corporation. 
The European Union Chamber of Commerce (2020, 2 July). Stance on the updated Negative List for Foreign Investment. Pobrane z: https://www .europeanchamber.com.cn/en/ press-releases/3253/stance_on_the_updated_negative_list_for_foreign_investment.

The Free Trade Zone Special Administrative Measures on Access to Foreign Investment (2020 edition) (“2020 National Negative List") (2020, July). Pobrane z: https:// www. dezshira.com/library/ legal/FTZ-free- trade-zone-special-administrative-measures-foreign-investment-2020-national-negative- list.html?1593599181.

The Special Administrative Measures on Access to Foreign Investment (2020 edition) ("2020 National Negative List") (2020, July). Pobrane z: https://www.dezshira.com/library /legal/special-administrative-measures-access-foreign-investment-2020-edition -national-negative-list.html?1593598930.

Thornton, A. (2019, 6 February). 10 cities are predicted to gain megacity status by 2030. World Economic Forum. Pobrane z: https://www.weforum.org/agenda/ 2019/02/10-cities-are-predicted-to-gain-megacity-status-by-2030/.

Verdier, D. (2002). Moving Money. Banking and Finance in the Industrialized World. Cambridge: Cambridge University Press.

World Bank, People's Bank of China (2018). Toward Universal Financial Inclusion in China: Models, Challenges, and Global Lessons. Washington and Beijing.

Wójcik, D. (2013). The dark side of NY-LON: Financial centres and the global financial crisis. Urban Studies, 50(13), 2736-2752.

Wójcik, D., Pažitka, V., Knight, E., O’Neill, P. (2019). Investment banking centres since the global financial crisis: New typology, ranking and trends. Environment and Planning A: Economy and Space, 51(3), 687-704.

Wu, F., Xu, J., Yeh, A.G. (2007). Urban Development in Post-reform China. State, Market, and Space. London-New York: Routledge.

Yan, Z., Zhu, J. (2020, 27 March). Goldman, Morgan Stanley receive approvals for majority stakes in China ventures. Pobrane $\mathrm{z}$ : https://www.reuters.com/article/ us-morgan-stanley-china-idUSKBN21E1AO.

Yugui, Z. (2020, 27 February). Is Shanghai on track to becoming an international financial centre in 2020? ThinkChina. Pobrane z: https://www. thinkchina.sg/ shanghai-track-becoming-international-financial-centre-2020.

Yusuf, S., Weiping, W. (2001, 30 June). Shanghai rising in a globalizing world. World Bank Policy Research Working Paper, WPS2617.

Z/Yen Group, China Development Institute (2021, 10 March). The Global Financial Centres Index 29. London - Shenzen. 